\title{
Getting high with the most high: Entheogens in the Old Testament
}

\author{
DANNY NEMU* \\ Independent Researcher, Psychedelic Press, UK \\ (Received: November 20, 2018; accepted: January 20, 2019)
}

\begin{abstract}
This article collects evidence from psychopharmacology, scripture, and archeology to explore several preparations for consumption described in the Old Testament: Manna, Showbread, the Holy Ointment, and the Tabernacle Incense. The Ointment and the Incense are herbal preparations used by the priestly caste to facilitate a direct experience of the Israelite God. A wide variety of psychoactive components are found in these preparations, including GABA-receptor agonists and modulators, opioid receptor agonists, and other agents. They are normally broken down by the body's enzymes, and therefore orally inactive, but the Holy Ointment also contains inhibitors specific to the enzymes in question. The preparations indicate that the ancient Israelites had a profound understanding of synergism, and the way they are consumed and the taboos around them are highly suggestive of their use as psychoactive agents.
\end{abstract}

Keywords: entheogens, Bible, Manna, ergot, enzyme inhibition, synergism, herbalism, psychedelics

\section{INTRODUCTION: SHAMANISTIC PRACTICES AMONG THE ANCIENT ISRAELITES}

Definitions of shamanism are contested and problematic, and yet consistencies are observed between societies around the globe and across time. Winkelman (2013) surveyed "recognized magico-religious practitioners" in 47 traditional societies, and compiled a list of cultural motifs:

- a dominant social role as the preeminent charismatic leader;

- a nighttime community ritual;

- use of chanting, singing, drumming, and dancing;

- an initiatory crisis involving a death and rebirth experience;

- shamanic training involving induction of an altered state of consciousness (ASC), particularly with fasting and social isolation;

- an ASC experience characterized as a soul journey (but not possession);

- ASC involving visionary experiences;

- abilities of divination, diagnosis, and prophecy;

- healing processes focused on soul loss and recovery;

- illness believed to be caused by spirits, sorcerers, and the intrusion of objects or entities;

- animal relations as a source of power, including control of animal spirits;

- the ability of the shaman to transform into animals;

- malevolent acts or sorcery, including the ability to kill others;

- hunting magic, assistance in acquiring animals for food.

Nearly every item appears in the legends of Moses and his siblings (whether they existed is immaterial; the literature demonstrates that the Israelites were familiar with shamanistic tropes). Moses is initiated into his special relationship with YHWH during an ASC with visionary experiences at the burning bush (Exodus 3:2), and YHWH prophesies that he will lead the Israelites to freedom (Exodus 3:18-21). Although Moses complains that he is not up to the task of challenging Pharaoh (Exodus 3:11), YHWH promises to act as an ally and give him charisma and eloquence: "I will be with thy mouth, and teach thee what thou shalt say" (Exodus 4:12). He assumes his role as leader of the Israelites, and the initiation concludes with a brush with death when "YHWH met him, and sought to kill him" (Exodus 4.24).

While the prophet does not transform into an animal, his staff turns into a snake (Exodus 4:4), as does his brother Aaron's in a magical battle against Egyptian magicians (Exodus 7:10-12). Other powers include malevolent sorcery controlling animals, as when "Aaron stretched out his hand over the waters of Egypt; and the frogs came up, and covered the land" (Exodus 8:6), as well as causing disease in the form of boils (Exodus 9:10) and killing (Exodus 11:4-5).

Moses mediates between YHWH and the tribe, sometimes presenting his utterances in song (Exodus 15:1). His sister Miriam the prophetess follows his songs with her own, playing percussion and leading a dance (Exodus 15:20). Moses also instigates three nighttime community rituals per year (Perez, 2001, p. 257; Exodus 23:14-16). Both the means and objectives of divinatory rites in the Tabernacle follow the shamanic format, with the mysterious urim and thummim (Exodus 28:30) as divinatory tools in the place of the shaman's shells or bones (Vitebsky, 2001, p. 104). Shamans working to protect their tribes traditionally divined for military tactics (Fausto, 2012) as does Moses (Exodus 14:1-4), and for life's necessities, as YHWH guides Moses to game (Exodus 16:11) and water (Exodus 17:6). Moses

* Corresponding address: Danny Nemu; Independent Researcher, Psychedelic Press, UK; E-mail: thereverendnemu@gmail.com

This is an open-access article distributed under the terms of the Creative Commons Attribution-NonCommercial 4.0 International License, which permits unrestricted use, distribution, and reproduction in any medium for non-commercial purposes, provided the original author and source are credited, a link to the CC License is provided, and changes - if any - are indicated. 
also diagnoses the cause of diseases afflicting both the collective (Exodus 32:31-33) and individuals (Numbers 12:11-14), and barters with YHWH to mitigate harms.

The only absence from the Tabernacle stories is the soul journey, although it was probably as familiar to the Israelites as it was to the 47 societies surveyed; the stories of the prophets are suggestive: "And Enoch went with Elohim: and he was not; for Elohim took him" (Genesis 5:24, my translation). Perhaps Moses simply did not need to work that way as he was a super-prophet; "YHWH spake unto Moses face to face, as a man speaketh unto his friend" (Exodus 33:11). "There arose not a prophet since in Israel like unto Moses, whom YHWH knew face to face" (Deuteronomy 34:10). Other techniques are shamanistic. Shamans undergo isolation and fasting to receive icaros, or distinctive phrases of melody and phonemes that transmit the power of a given plant, animal, or elemental ally. There is a clear echo in the story of Moses upon Mount Sinai, where the word usually translated as "covenant" can also be "alliance."

And he was there with YHWH forty days and forty nights; he did neither eat bread, nor drink water. And he wrote upon the tables the words of the alliance, the ten words/ phrases (Exodus 34:28, my translation) [These are "ten words/phrases/utterances," not "ten commandments" as in most translations. They are not the well-known thou-shalt-nots (Nemu, 2016, pp. 13-15).].

Medicine-men of the Amazon jungle or Siberian plains go into their huts alone to encounter their familiar spirits. The High Priest enters the Holy of Holies alone to commune with YHWH before the Ark of the Covenant/Alliance. Israelite priests, like some shamans, used plant preparations entheogenically to facilitate the encounter, to trigger visionary, auditory, and other ASC experiences of divinity. The complex mixtures of Holy Ointment and Holy Incense will be examined, along with Manna and the Showbread.

\section{OLD TESTAMENT ENTHEOGENIC HYPOTHESES}

The implications of entheogen use in the Bible go beyond ethnographic curiosity. The Old Testament and its daughters the New Testament and the Koran continue to guide the philosophical orientation of many people today, and are influential standards for proper conduct in morality, politics, and law. Given the brutal reality of the War on Drugs and the continuing human interest in mystical experience, drugs, and scripture, it is no surprise that several attempts have been made to mine the Bible for evidence of entheogens. Before presenting my own evidence, I will review some other publications.

\section{AYAHUASCA ANALOGUE}

Shanon (2008) proposed that an ayahuasca analogue was made by brewing one of the locally abundant DMT-containing acacia species with Peganum harmala, which contains the monoamine oxidase (MAO)-inhibitor harmaline. P. harmala is harmal in Arabic, and Shanon relates the word to cherem meaning "taboo" in Hebrew, and also the Arabic haram that means both "taboo" and "sacred." The Biblical acacia is called shittim, derived from shotet meaning "to pierce" (Strong's, H7850), which describes what DMT does to the veil of everyday reality (as well as what acacia thorns do to the skin). Whatever it was, and the species is disputed, it was the most exalted wood used to construct the Ark of the Covenant (Exodus 26:15).

The Talmud, which is a collection of oral folklore and law written down from the first century $\mathrm{AD}$, also relates the esteemed shittim to shtuth meaning "nonsense" (Mishna. Sanhedrin, 106a) - a rather irreverent pun that makes more sense if the psychedelic effects of DMT are considered. The Talmud also records a serenade:

Sing, $O$ sing, shittim tree,

Ascend in all thy gracefulness.

With golden weave they cover thee,

The sanctuary-palace hears thy eulogy (Mishna. Abodah Zarah, 24).

Given that wood neither sings nor eulogizes nor rises, this poem might contain veiled references to the entheogenic use of shittim or perhaps the rising smoke of shittim incense triggering clairaudient effects.

I would add to Shanon's hypothesis evidence from the Islamic tradition. Harmal "expels devils and averts misfortune," according to one hadith or saying of the prophet Muhammad (Flattery \& Schwartz, 1989, p. 63). Another recommends large daily doses both for cure and insight:

Whoever takes a mithqual [4.25 grams] of harmal in water for 40 mornings each day, so shall wisdom enlighten his heart, and he shall be healed of/immune to seventy-two diseases. (Quoted in Rooks, 2014)

Shanon cites verses that suggest two psychedelic phenomena. One is a fire that burns upon objects but does not consume them (Exodus 24:17), which he interprets as a visual metaphor for the brilliant patterns that blaze around objects in psychedelic states. The other is synesthesia or the mixing of sense modalities:

And all the people are seeing the voices, and the flames, and the sound of the trumpet. (Exodus 20:18, YLT)

While an ayahuasca analogue may have been used in the ancient Middle East, there is no direct evidence of it in the Bible and no known reference to P. harmala at all. Some psychoactive ingredients may have gone unreported, certainly, as much of the oral tradition has been lost. For example, while there is no obvious reference to henbane in Jewish scripture, the ex-priest Josephus leaves a description of the High Priest's ceremonial hat decorated with the design of a henbane flower (Feliks, 2001), which contains the powerful hallucinogenic deliriant scopolamine (Blom, 2009 , p. 134). To my knowledge, however, the synesthesia 
and visions are better explained by Merkur (2000), who argued that the Manna consumed before the Sinai episode was ergot.

\section{ERGOT IN THE OLD TESTAMENT}

\section{Manna}

The ergot fungus parasitises a range of plants (Zadoks, 2008) and produces a secretion that contains ergotamine. Although ergot can be toxic, the powerful visionary D-lysergic acid amide (LSA), can be prepared from it. Hofmann, who used ergot to synthesize lysergic acid diethylamide (LSD), commented:

The separation of the hallucinogenic agents by simple water solution from the non-soluble ergotamine and ergotoxine alkaloids was well within the range of possibilities open to Early Man. (Wasson, Hofmann, \& Ruck, 1976, p. 11)

The Bible describes this process, by people who "ground it [Manna] in mills, or beat it in a mortar" (Numbers 11:8), then boiled it and baked it. Merkur also argues that this process would extract psychoactive alkaloids from ergot, and how "Manna was like coriander seed and looked like resin" (Numbers 11:7, NIV); or elsewhere "white, like coriander seed and tasted like wafers made with honey" (Exodus 16:31). The honeydew ergot produces tastes like honey (Zadoks, 2008) and dries on the plant as small, resinous, white pellets roughly the size of coriander seeds. Merkur does not adequately explain the other description of Manna as "thin flakes like frost on the ground" (Exodus 16:14); however, it also describes ergot, as the honeydew splashes where it drips and dries as a thin, white frosty scale.

Any guess as to the identity can only be speculative several thousand years later, but other evidence Merkur does not cite supports the hypothesis. For example, several problems with the normal reading of scripture are resolved if Manna is identified as ergot:

And when the children of Israel saw it, they said one to another, "It is Manna" (man hoo): for they wist not what it was." (KJV, Exodus 16:15)

The KJV translation is illogical, because if "they wist not what it was" then how did they know to call it Manna? The HNV and NLT Bibles translate man hoo as "what is it?," but this presents a problem raised by the 15th-century Rabbi Isaac Arama, who noted that a question would demand that "the wording should have been 'they asked one another' instead of 'they said to one another" (Ron, 2010). Also "what" is $m a$ in Hebrew, not man. The Rashbam proposed that the Israelites had picked up the Egyptian word for "what" (which is man) (Ron, 2010), but it is strange to use this single loanword when the rest of their vocabulary was Hebrew. In addition, in another commentary the Israelites maintained their own language in Egypt (Mishna. Leviticus Rabbah 32:5).
Man hoo can also simply mean "it is man," where man is a Bedouin word for a sugary secretion excreted by insects that feed on plant sap. It hardens to form whitish resinous pellets that taste like honey, and Bedouins collect it as a foodstuff. Bodenheimer (1947) and others conclude that Manna is man, but if this is the case then the Israelites' identification would be correct, and "for they wist not what it was" presents a logical contradiction again. It is more parsimonious, without the logical, linguistic, lexical, and rabbinical contradictions, to interpret the verse as the Israelites thinking it was man in error ("for they wist not what it was"). It would have been a reasonable guess at first encounter because desert people would have been familiar with man. On closer inspection, the error would become clear. Man is viscous, not runny like ergot; it forms globulous mounds where it drips, not "thin flakes," and cannot be ground or beaten in a mortar (Bonar, 1857, pp. 146-151). Ergot secretion, on the other hand, dries brittle and can be ground to powder.

Another problem is that Bedouin man can be stored for a year or more, but with Manna:

Moses said, "Let no man leave of it till the morning." Notwithstanding they hearkened not unto Moses; but some of them left of it until the morning, and it bred worms, and stank... (Exodus 16:19-20)

Such rapid decay supports the thesis of ergot infection, as does the fact that heat arrests the infection:

And he said unto them: "To morrow is the rest of the holy sabbath unto YHWH: bake that which ye will bake to day, and boil that ye will boil; and lay up what is left over [from what you have made] until the morning." And they laid it up till the morning, as Moses bade: and it did not stink, neither was there any worm therein. (Exodus 16:23-24, my translation)

The environmental context also supports Merkur. Ergot emerges from dormancy at the onset of spring, which is when the Israelites first encounter it (Alderman et al., 1999; Midrashim. Mekhilta Exodus 16:1). Furthermore, a parasitic fungus requires vegetation and therefore water. Manna is not found in the Wilderness of Shur, which is dry, but in the Wilderness of Sin where there is water.

Manna is not the only food the Israelites find, as quails also come to ground every night to be rounded up. This seems more remarkable than a plant secretion not unlike others known to desert peoples, and yet only Manna is called "angel food" (Psalm 78:25). Perhaps this is not because it comes from the angels but because people who eat it encounter angels. The quail meat is barely mentioned, and when it is a feeling of satisfaction is attributed not to it but only to Manna (here referred to as bread).

At evening you shall eat meat, and in the morning you shall be satisfied with bread (Exodus 16:12, my translation).

It suggests that Manna satisfies in a more profound way than meat. 
As they leave the Wilderness Moses issues a command that Manna was to be kept for future generations:

And Moses said, "Fill an omer of it to be kept for your generations; that they may see the bread wherewith I have fed you in the wilderness." (Exodus 16:32)

He immediately contradicts himself the following verse:

And Moses said unto Aaron, "Take a pot, and put an omer full of Manna therein, and lay it up before YHWH, to be kept for your generations. "As YHWH commanded Moses, so Aaron laid it up before the Testimony, to be kept. (Exodus 16:33-34)

The Manna to be seen ends up hidden behind veils in the inner chamber of the Tabernacle. Stranger still, the command is issued, and followed, even though the Tabernacle has not been constructed yet. Textual scholars (Baden, 2010) conclude that this line is an interpolation introduced to the text at a later date. Merkur reasons that this is because the entheogenic experience became off-limits to the general population. Ergot can be cultivated in pots, and the priestly caste could have kept it to themselves, while for everyone else, "there was no longer any manna for the Israelites" (KJV. Joshua, 5:12). Entheogenic preparations were mostly confined to the Tabernacle: Ointment, Incense, Showbread and eventually Manna as well.

\section{Showbread}

Merkur argues that showbread was also ergot, citing cryptographical references in the Talmud and elsewhere, but here the evidence is less robust. One bizarre Talmud story Merkur does not cite makes more sense if we suppose that the showbread was psychoactive, though whether it contains ergot is unclear:

In [High Priest] Simeon the Upright's time... every priest who received only the size of an olive became satiated, and some was left over... But after him, these things were cursed, and every priest got only the size of $a$ bean. And the delicate priests refused to take it altogether, but the voracious ones accepted and consumed. It once happened, one took his own share and his fellow's: he was nicknamed "robber" till his death. (Mishna. Tractate Yoma 4)

Tiny, carefully measured doses suggest psychoactives rather than sustenance, as does the observation that some priests wanted more, while for others even one dose was too much to handle. The fact that it is served along with frankincense (Leviticus 24:6-7), the psychoactive and synergistic properties of which will be discussed below, strengthens the case for it being psychoactive.

Showbread in Hebrew is lechem ha-panim, literally "bread of faces/presences." When "Adam and his wife hid themselves from the presence of YHWH Elohim" (Genesis $3: 8$ ), and when "YHWH spake unto Moses face to face" (Exodus 33:11), the "presence" and the "face" are that same words. Perhaps showbread was eaten to perceive divine presences - which was also the function of both the Ointment and the Incense to be discussed below.

\section{TABERNACLE WINE}

Psychoactive alkaloids were extracted into wine in Ancient Greek, Chinese, Saxon (McGovern, 2003, p. 132; Rinella, 2010 , p. 8) and many other cultures. Eschotado (1998, pp. 57-58) hypothesizes that the story of Lot impregnating his daughters while drunk only makes sense if:

some sort of admixture was added to the wine analogous to the Egyptian nepenthes, though distinct in composition - capable of giving Lot the extraordinary energy required to overcome the taboo of incest, provoking total unconsciousness and hyperactivity at the same time... amnesia and complete ethical insensitivity... [while allowing] a considerable featfor an elderly man - to deflower and impregnate two maidens on successive nights, without even realizing it. (my translation)

"Ointment and incense rejoice the heart," reads Proverbs 27:9, where the word for "rejoice" (samach) also describes the effect of wine (Judges 9:13). I will argue that the moodaltering and entheogenic effects of Ointment and Incense derive from their psychopharmacology.

\section{THE HOLY OINTMENT}

\section{Identities of the Ointment ingredients}

Take thou also unto thee principal spices, of pure myrrh five hundred shekels, and of sweet cinnamon half so much, even two hundred and fifty shekels, and of kaneh bosm two hundred and fifty shekels. And of cassia five hundred shekels, after the shekel of the sanctuary, and of oil olive an hiyn: And thou shalt make it an oil of holy ointment, an ointment compound after the art of the apothecary (Exodus 30:23-4).

Myrrh (mor) was given to the infant Christ. It features extensively in Jewish and Christian ritual, and in Egyptian ritual since at least 2800 BCE (Graham, 2015). Candidates include Commiphora abyssinica, Commiphora schimperi, Commiphora guidotti, Commiphora africana and Commiphora myrrha (Ben-Yehoshua, Borowitz, \& Hanuš, 2012). Some speculate that mor refers to both the more fragrant $C$. guidotti and the more medicinally potent C. myrrha (Thulin \& Claeson, 1991, pp. 487-494). Perhaps it is significant in this regard that the Ointment recipe is the only biblical use of the compound noun "pure/flowingmyrrh" (mor-d'rowr). Elsewhere it is mowr abar, "sweetsmelling myrrh," (Song of Solomon 5:5) or simply mor. The "wine mingled with myrrh" offered to Jesus at his execution (Mark 15:23) implies analgesic effects, and C. myrrha is certainly analgesic. This article will focus on C. myrrha. Cassia is most likely Cinnamomum cassia (Ben-Yehoshua et al., 2012). 
Regarding cinnamon, Zohar Amar wrote the most thorough account of the contenders and settled upon Cinnamomum verum (Ben-Yehoshua et al., 2012).

Kaneh bosm means "fragrant cane." Though translated as "calamus" (Acorus calamus) since the first Greek translation of the Bible in the 3rd century BC, anthropologist Benet (1975) argued that the correct identity is cannabis. A. calamus is unlikely as Israelites buried their dead in kanabos shirts. Cannabis clothes have been used for millennia, but no one ever made textiles from this grasslike plant, and such a shirt would decompose within days. Benet argues that kaneh bosm, a phrase fused into the single word kanabos or kanabus later in Jewish writings, is what was called kannabis in the Scythian lands to the north of Israelite territory, and called "cana in Sanskrit, qunnabu in Assyrian, kenab in Persian, kannab in Arabic and kanbun in Chaldean." In the 6th century BC, Herodotus observed Scythian tribesmen pegging down the flaps of their tent and throwing kannabis on red-hot stones:

immediately it smokes, and gives out such a vapor as no Grecian vapor-bath can exceed; the Scyths, delighted, shout for joy. (Herodotus, 1996, p. 330)

Cannabis residues from ancient Scythian vessels support Herodotus' observation (Graham, 2015), and cannabis was was found in the mummy of Rameses II (Parsche \& Nerlich, 1995). It was likely introduced to Egypt along trade routes through Israelite territory (Bennett, 2010, p. 350). In Jeremiah 6:29, kaneh (the shortened form of kaneh bosm) is described as "from a far country." A dig near Jerusalem from the mid-second millennium BC uncovered hashish in forms suggesting both transdermal application and fumigation (Zias et al., 1993). Bennett (2010) presents extensive evidence from literature, linguistics, and archeology in support of kaneh bosm being cannabis, and his theory has gained traction among ministers, rabbis, linguists, archeologists, anthropologists, botanists, and others (Bennett, 2010, pp. 356-358). This would clearly have implications for the psychoactive properties of the Ointment, but even if we dismiss this line of inquiry as speculation the pharmacology of other ingredients suggests an entheogenic mixture.

\section{USAGE AND POSSIBLE PROVENANCE OF THE OINTMENT}

The Holy Ointment was likely applied by massage. It is called shemen ha-mishchah, where shemen means "oil" and mishchah derives from mashach meaning "to rub with oil, i.e. to anoint; by implication, to consecrate; also to paint" (Strong's H4886). The king was a direct link between YHWH and His Chosen People, and that connection was established by the Rite of Anointing that initiated his reign:

Then Samuel took the horn of oil, and anointed/ massaged him in the midst of his brethren: and the Spirit of YHWH came upon David from that day forward. (1 Samuel 16:13)
David, Saul, and other kings are referred to as "anointed person," or mashiyach in Hebrew (by the time it was Latinized as messiah the meaning had drifted considerably). A connection with YHWH triggered by Ointment also appears to have been a prerequisite for priests anointed "that they may minister unto Me [YHWH] in the priest's office" (Exodus 30:30).

Egyptian medicine also employed cannabis oil (Nunn, 1996), and a massage oil combining the other ingredients myrrh, cassia, and cinnamon - was exported by Egyptian apothecaries from the Middle Bronze Age (Aegineta, 1847, p. 595). This and the use of the Egyptian measurement of "an hiyn" in the recipe suggests that it may derive from Egypt (Gesenius, 1857, p. 223) (other evidence connecting the priestly caste to Egypt is discussed in Nemu, 2016, p. 276). As in Egypt, the Israelite priests held taboos regarding priestcraft and medicine (Gordon \& Schwabe, 2004, p. 187; Sauneron, 2000, p. 23). One forbade making the mixture for any other purpose or putting it upon a commoner. Another taboo kept the session contained and the setting controlled:

And ye shall not go out from the door of the Tabernacle of the congregation, lest ye die: for the anointing oil of YHWH is upon you. (Leviticus 10:7)

\section{CONSTITUENTS OF THE HOLY OINTMENT INGREDIENTS}

C. myrrha (myrrh) contains among its components large amounts of the furanosesquiterpenoids 2-acetoxyfuranodiene $(9.80 \%)$, furanoeudesma-1,3-diene $(8.97 \%)$, curzerene $(6.71 \%-17 \%)$ and furanodiene, as well as $\alpha$-pinene, limonene, cuminaldehyde, eugenol, safrole, myrcene, and elemicin (Duke, 2002; Hanuš, Rosenthal, ezanka, Dembitsky, \& Moussaief, 2008).

C. verum (cinnamon) also contains cinnamaldehyde and eugenol, but in much greater quantities than myrrh (65\%-80\% and $10 \%$, respectively), along with linalool, safrole, myrcene, $\beta$-caryophyllene, and cinnamic aldehyde (Asghar, Irshad, \& Majeed, 2016; Parthasarathy, Chempakam, \& Zachariah, 2008, p. 129; Rao \& Gan, 2014).

The most significant chemical difference between C. verum and Cinnamomum cassia is that the latter contains estragole (Liao et al., 2012) and particularly coumarin while the former has "hardly any" (Ooi et al., 2006; Ranasinghe et al., 2013).

Cannabis sativa contains tetrahydrocannabinol (THC), cannabidiol (CBD), and a wide range of phytocannabinoids, as well as nerolidol and phytol. Also present are various terpenes found in myrrh, cinnamon and cassia, including limonene, myrcene, $\alpha$-pinene, linalool, $\beta$-caryophyllene, caryophyllene oxide, and cinnamaldehyde.

\section{Synergistic interactions}

Traditional medical modalities such as Chinese herbalism and Indian Ayurveda usually employ mixtures that work together (Ebadi et al., 2016). Amazonian shamans make 
ayahuasca, and its powerful effect is because one of the ingredients inhibits the body's MAO enzymes and another contains DMT, which is orally effective only when MAO enzymes are inhibited and do not prevent DMT crossing the blood-brain barrier. Mixtures can produce entheogenic effects of a totally different order to ingredients taken alone.

Persian medicine uses "convoy medicines" (mobadregh), and their mechanism is to "increase the bioavailability of coadministered drugs by inhibition of P-gp or cytochrome P450 [enzymes]" (Sadati et al., 2016). One common convoy medicine is cinnamon, which is also found in the Ointment. It is critical to its entheogenic properties because the psychedelic chemicals in myrrh and cassia are usually broken down by the P450s, five of which are involved in approximately $99 \%$ of P450-mediated drug metabolism (Bertz \& Granneman, 1997). Cinnamon inhibits four of them: CYP3A4, CYP2C9, CYP1A2, and CYP2E1 (Kimura, Ito, \& Hatano, 2010; Sadati et al., 2016). It does not inhibit the fifth, CYP2D6, but the coumarin in cassia reduces its activity by over $90 \%$ (Hiroshi et al., 2004; Ranasinghe et al., 2013). The amount of coumarin in cassia is generally less than 2.7\% (Jayatilake, Poole, Poole, \& Chichila, 1995), which may be why the recipe stipulates twice as much cassia as cinnamon.

P450 function has a profound effect on how drugs interact with the body. CYP2C9 breaks down THC, and people who metabolize it poorly have been shown to have three times the concentration of THC than those who metabolize it well (Sachse-Seeboth et al., 2008). CYP3A4 also plays a major role in THC metabolism (Stout \& Cimino, 2013), so the inhibition of these two enzymes would increase the duration and the effect of cannabis. Linalool (Meesters, Duisken, \& Hollender, 2007), estragole, eugenol, and other psychoactive chemicals discussed below are also broken down by P450s.

\section{Diet and genetics}

A complete picture of the synergies would consider other factors from the fields of archeoethnography and archeogastronomy. Regional populations vary in terms of P450 profiles (Bertz \& Granneman, 1997, p. 213), meaning that some medicines are cleared faster by Caucasians than Asians (Bond, 1991). An example of a significant dietary factor is pomegranate, which is a CYP3A inhibitor in the acute phase (Hidaka, 2005), and alters the expression of genes coding for both CYP1A2 and CYP3A enzymes over the longer term (Faria \& Calhau, 2011). Given that CYP1A2 is likely made more active by THC (Stout \& Cimino, 2013), and that it breaks down coumarin (Stout \& Cimino, 2013), pomegranate could profoundly affect the altered state occasioned by a mixture of resins. Ancient Israelites may have known about this synergy:

Thy plants are an orchard of pomegranates, with pleasant fruits; henna, with spikenard. Spikenard and saffron; cane [kaneh] and cinnamon, with all trees of frankincense; myrrh and agar-wood, with all the chief spices. (Song of Songs 4:13-14, my translation)
All of the plants in this paradisiacal garden contain known psychoactive compounds, with the exception of pomegranate and henna. Henna may have some yet to be identified compounds, as it is traditionally used as a sedative and aphrodisiac (Miczak, 2001, p. 85), but in any case every plant except pomegranate is either psychoactive or believed to be psychoactive. Although "the pomegranate probably played a relatively minor role in the diet of Israelites" (MacDonald, 2008, p. 30), eaten in quantity it would contribute to the psychoactive potential of the other substances. This may explain why a large quantity is emphasized, as in "an orchard of pomegranates."

\section{Further evidence for synergism}

Several other lines of evidence support the hypothesis of complex synergisms unlocking entheogenic potentials. First, the community of "oilahuasca" researchers procures ASCs by mixing essential oils that contain psychedelic compounds and the relevant inhibitors. Before gas chromatography and the rat-on-a-hotplate test, herbalists used a similar combination of self-experimentation, peer-to-peer conversation and insight to explore their pharmacopoeia.

Further support for the entheogenic capacities of the Ointment is that it contains a terpene spectrum somewhat similar to that of nutmeg. Nutmeg is almost unique among spices in that it contains a wide range of inhibitors as well as psychoactive agents, so if an individual has the appropriate P450 spectrum it triggers "hallucinations that can last up to 48 hours" (Wenk, 2010, p. 63). Missing the dosage window results in either disappointment or a dreadful headache (so take care), but the ideal dose can result in:

intensely pleasurable tactile sensations, that seemed to send shivers up my spine every time I acknowledged them. The only thought going through my head at this time was, what a wonderful life I have. (Biologyguy, 2013)

This description suggests MDMA, which makes sense given that components include elemicin, eugenol, and safrole (Nowak, Woźniakiewicz, Gładysz, Sowa, \& Kościelniak, 2016). All of these are related to MDMA, and are found in the Holy Ointment.

Furthermore, potent synergy between nutmeg and myrrh has been reported. The Kalachakra Tantra describes the combination as like the union of male and female from which "a pure knowledge arises, which explains the nature of all things" (Douglas \& Slinger, 2000, p. 245) and one self-experimenter's experience featured "a fierce and aggressive deity... visions of a bulging-eyed, white-skinned man in ceremonial armour... [and] new knowledge disclosed" (Mr. Sunday, 2013). Although one might have assumed his "set" would be colored by the sexual poetry of the tantric text, the martial and revelatory themes are interesting given that he had unknowingly consumed many of the terpenes in an Ointment used to trigger a revelation of YHWH, a god of war and "great terrors" (Exodus 15:3; Deuteronomy 4:34) and a source of insight.

Little can be inferred from a single report, but in any case the Ointment contains powerfully psychoactive agents and inhibitors of the enzymes that metabolize them, and this is 
sufficient to demonstrate a physiological mechanism by which its extraordinary effects could be generated in the human body.

\section{PSYCHOPHARMACOLOGY OF THE HOLY OINTMENT}

\section{Distribution modification}

Limonene and eugenol increase the absorption of chemicals across the skin (Varman \& Singh, 2012). Cinnamaldehyde dilates the peripheral capillaries of the vascular system, increasing blood flow and helping to distribute any terpenes absorbed (Harada \& Yano, 1975).

\section{Adenosine receptor agonism}

Limonene is also an adenosine $\mathrm{A}(2 \mathrm{~A})$ receptor agonist (Park, Lee, Yaoyao, Jun, \& Lee, 2010) that impacts serotonergic and dopaminergic function in brains of the mice (Kendall \& Alexander, 2017, p. 87). These two neurotransmitters are involved in many of the mechanisms described below and may contribute to cumulative effects on the subjective experience.

\section{Opioid receptor agonism}

C. myrrha contains furanosesquiterpenoids active at $\mu$ - and $\delta$-opioid receptors, including curzarene, furanodiene, and furanoeudesma-1,3-diene (Dolara et al., 1996). Their analgesic properties have been established in mice by measuring the latency of their pain reaction on a hot plate and the amount of writhing after an injection of acetic acid. Furanoeudesma-1,3-diene was found to have $10 \%$ of the potency of morphine, which makes sense of the "wine mingled with myrrh" offered to Jesus during his execution (Mark 15:23). Perhaps he refused because it has other effects:

While $\mu$ opioids continue to be some of the most effective analgesics, they are also efficacious mood enhancers and cause activation of central dopamine reward pathways that modulate euphoria. (Al-Hasani \& Bruchas, 2011)

Traditional communities in Africa consume myrrh at social gatherings, suggesting social lubrication or mood-enhancing properties (Yaniv \& Dudai, 2014), and the myrrh-infused wine Pliny mentions at Roman feasts (1601, Chapter 13) was presumably valued for such effects rather than as a painkiller. Myrrh is effective even in the absence of synergism. The effects of insufflation (snorting) are described by one psychonaut as,

instant and profound. Stronger than Blue Lotus but not as strong as Kratom. The effects are a relaxed stimulation, a profound clear focus, mild euphoria, relief of body aches and anxiety (Unknown source, quoted in Moonshoe, 2015)

Another describes six drops of myrrh essential oil in water:

My body feels alive with electricity... a euphoria washes over my that grows in intensity by the minute... everything is starting to feel rather dreamlike... Pupils constricted, not quite pinpoint [as is seen with heroin] but smaller than normal. (DMtriptamine285, 2012)

The same individual also tried transdermal application:

the stimulation wasnt [sic] as strong. I found it actually more euphoric however than taking the oil orally.

Other reports are reminiscent of heroin:

Within minutes after taking like 5-10 nice big hits of myrrh... I notice an immediate tranquil/chill effect... that feeling of "nothing in the world bothers you, everything is just perfect at the current time, you feel completely at rest with the world." (Ascendancy-Mike, 2009)

$I$ was working with the $5 x$ extract vaporized, and the ground, whole myrrh resin ... a few times, I had experiences that were divine with just the myrrh alone. (Jacky, 2009)

Poorly spelt accounts of anonymous individuals with wacky avatars in data sets of one do not carry the credibility of animal models in science, but they can tell us something about how myrrh and mindset combine to produce profound and even "divine" entheogenic experiences.

\section{MDMA-like compounds}

Relatives of MDMA in the Ointment include eugenol, estragole, elemicin, and safrole; the illegal stimulant and empathogen is usually manufactured from the latter. MDMA both releases serotonin, norepinephrine, and dopamine into the synapse and slows down reuptake of the same. Eugenol, estragole, elemicin, and safrole all have measurable effects on animal behavior. Safrole causes "extreme inhibition" to locomotor activity of mice on a wheel (Muchtaridi, Subarnas, Apriyantono, \& Mustarichie, 2010). Elemicin is structurally close to mescaline; one report describes "lots of euphoria, mild psychedelic effects, mild visuals, feeling fantastic" (69ron, 2010). Rätsch (2005, p. 835) presents research indicating eugenol's stimulant and psychoactive properties; the latter is confirmed by a psychonaut who ate $30 \mathrm{~g}$ of cloves (with a high eugenol content) and reported "falling constantly into some abyss inside of myself, lights are distorted... I cant really walk because I feel so dizzy, numb, and tired" (Halcpath, 2007). Estragole is found in high concentrations in sweet basil (Ocimum basilicum L.; Joshi, 2014). Twenty-five drops of sweet basil essential oil taken after star anise tisane gave one psychonaut:

a euphoric \& energetic trip with Lysergic [LSD]/Psilly [psilocybin] head-spaces and a warm and fuzzy body feel; but may have been a drop or two too much for me as it gave some jittery stimulation but was, all in all, really really nice. (Flickedbic, 2014)

Another experiment by the same individual combined cinnamon, pomegranate, cayenne pepper, star anise, and chai along with 26 drops of sweet basil and a little cannabis: 
Ifelt like I had a warm fuzzy blanket wrapped around me without CYP2D6 inhibition; but with the CYP2D6 inhibition I feel that I AM that warm fuzzy blanket. (Flickedbic, 2011)

\section{GABA-receptor modulation}

At least $40 \%$ of inhibitory synaptic processing involves the GABA neurotransmitter (Bowery \& Smart, 2006), and "inhibitory GABA synapses participate in virtually every neuronal circuit and function of the nervous system" (Olsen, 1991). $\alpha$-pinene makes GABA receptors more receptive (Duke, 2002), increasing the inhibitory effect of GABA. Its vapor is hypnotic (sleep-inducing) and anxiolytic (antianxiety) in rats (Satou, Kasuya, Maeda, \& Koike, 2013). The latter was demonstrated by exploiting a rat's natural aversion to open spaces; they spend longer in open parts of a maze under the influence of $\alpha$-pinene.

Even a mild reduction in anxiety has striking effects on human cognition. Friedman and Förster (2001) asked two cohorts to perform a creative problem-solving test after completing a maze that was identical except for the cartoon illustration: a mouse seeking cheese in one, a mouse fleeing an owl in the other. The latter cohort performed half as well in creative problem-solving. Given that the psychoactive preparations of Exodus were used for divination, which could be conceptualized as an elaborate ritual of creative problem-solving, anxiolytic effects are significant.

Myrcene is a GABA-receptor modulator working in a similar way, with analgesic (Rao, Menezes, \& Viana, 1990) and muscle-relaxant properties (Vale, Furtado, Santos, \& Viana, 2002) in animal models. Escondido (2015) speculates that "myrcene is the major ingredient responsible for 'flipping' the normal energetic effect of THC into a couchlock [ie. catatonic] effect."

Linalool modulates both GABA and glutamate neurotransmitter systems (Brum, Emanuelli, Souza, \& Elisabetsky, 2001), and has anxiolytic properties (Souto-Maior et al., 2011). Mice show a $73 \%$ reduction in motility when exposed to an extremely low concentration of vapor $(4.22 \mathrm{ng} / \mathrm{ml})$ (Buchbauer, Jirovetz, Jäger, Plank, \& Dietrich, 1993). In human subjects inhaling linalool:

hearing environmental sound [birdsong, murmuring of a stream etc.] not only caused much more favorable impressions in a sensory test but was also accompanied by a greater decrease of the beta wave. (Sugawara et al., 1998)

\section{GABA-receptor agonism}

The GABA-receptor modulators described above not only potentiate the inhibitory effect of endogenous GABA but also any exogenous GABA-receptor agonists such as safrole. GABA-receptor agonists have an inhibitory effect on neurones, making them less likely to fire (Rueda et al., 2014), which is why the GABA-receptor modulator diazepam has sedative and mood-altering properties. On the whole, GABA-receptor agonists and GABA-receptor modulators would have a cumulative effect on the central nervous system and the entheogenic experience.

\section{Succinic semialdehyde dehydrogenase (SSADH) inhibition}

SSADH is an enzyme that breaks down GABA. It is inhibited by phytol (Bang et al., 2002), so the presence of this chemical would increase levels of GABA in the brain, adding to the cumulative effects of GABA inhibition.

\section{Phytocannabinoids and Cannabinoid receptor modulation}

Cannabis contains THC, $\mathrm{CBD}, \mathrm{CBN}$, and a wide range of cannabinoids whose psychoactive effects are treated elsewhere (Pertwee, 2016). This article will focus on less well-known chemicals.

Both myrrh and cinnamon contain $\beta$-caryophyllene, which activates cannabinoid CB2 receptors (Bento et al., 2011), making them more responsive to phytocannabinoids and other agonists.

\section{Acetylcholinesterase (ACH) inhibition}

$\alpha$-pinene is an ACH inhibitor (Perry, Houghton, Theobald, Jenner, \& Perry, 2000), delaying the metabolism of acetylcholine and increasing its concentration and duration in the synapse. $\mathrm{ACH}$ inhibitors have been shown to increase rapid eye movement (Buckley et al., 2011), which is related to both dreaming and trance states. In addition to psychoactive effects, these chemicals aid memory formation, and could possibly counteract short-term memory deficits induced by THC (Russo, 2011).

\section{Neuroprotection}

The ACH inhibition activity of $\alpha$-pinene may be one of many neuroprotective synergies. Techniques mitigating the negative effects of drugs were known to the ancients; Pliny recommends pine-nuts, which also contain $\alpha$-pinene, as an antidote to the effects of cannabis (Pliny, 1986, p. 164). The 10th-century Persian physician Al-Razi prescribed acidic fruits (containing limonene) to avoid the harms of cannabis (Lozano, 1993, p. 124). Other possible neuroprotective synergies in the Ointment include commiterpenes in myrrh that protect against neuronal cell death (Elufioye, Berida, \& Habtemariam, 2017), and components of cinnamon that target inflammatory pathways (Kannappan, Gupta, Kim, Reuter, \& Aggarwal, 2011).

\section{INHALATION IN THE TABERNACLE}

Nearly all of the sacred objects in the Tabernacle were anointed along with the priests, and the constant evaporation of volatile oils would have made the air rich in psychoactive chemicals. Inhaled terpenes have a high bioavailability via pulmonary intake, around $60 \%$ for $\alpha$-pinene and limonene (Falk, Hagberg, Löf, Wigaeus-Hjelm, \& Wang, 1990; Kohlert et al., 2000). Aromatherapists use a few drops of oils in normally ventilated rooms to elicit calmative, stimulant, aphrodisiac, motivational, focusing, and other effects, and their claims are supported by human studies 
showing modulation of mood, memory, and cognitive performance (Moss, Hewitt, Moss, \& Wesnes, 2008). The Levites were using much larger doses in the desert heat, and the design of the Tabernacle was optimized to trap sublimated chemicals, with four layers of fabric drawn tightly over a frame and pinned into the ground. The outermost was an unidentified leather that is used for shoes (Gesenius, 1857, p. 861), and presumably strong and fairly impermeable.

Nothing else in the Bible is described in anything like the detail of the construction of the Tabernacle, with over six chapters specifying everything from the exact length of its acacia planks to the space between rings fastening down the coverings (Exodus 25-31:10). At the back was a $4 \frac{1}{2}-\mathrm{m}^{3}$ chamber called the Holy of Holies used exclusively by the High Priest for communicating with the divine.

\section{THE HOLY INCENSE}

The Ark and a censer were the only objects allowed inside the Holy of Holies. Bennett (2010, p. 362) notes that it was constructed in the manner of other smoke chambers of the ancient world, where psychoactive materials were imbibed by fumigation as noted in Herodotus' description of Scythian culture. Along with the four layers of fabric, the veil was "one handbreadth thick" (Mishna. Chullin, 7), and as such seems designed to seal a smoke trap.

Like the Israelite High Priest, the Oracle at Delphi prophesied following fumigation in a chamber. She burned frankincense, myrrh, laurel, olibanum, and henbane in her cave (Fausto, 2012, p. 147), a mixture containing many of the same ingredients and chemicals as the Holy Incense, perhaps including henbane if we accept Josephus' account (Feliks, 2001). Egyptian priests burned kyphi incense in the Temple of Edfu (Michael, 2015, p. 4). As with the similarity of the Ointment to the Mendesium, there may be evidence of cultural transmission here as frankincense, myrrh, cinnamon, mastic, saffron, and spikenard are listed in both concoctions (Byl, 2012), and some unidentified ingredients may be common to both.

\section{INGREDIENTS}

The Incense is called ktoreth ha-samim in Hebrew, where ktoreth means "incense." Samim is "drugs," in Modern Hebrew, including MDMA and heroin (Gilad, 2013). While biblical Hebrew is different from Modern Hebrew, "the Incense of Drugs" seems appropriate here. Shanon (2008) and others have proposed that it may have contained psychoactive ingredients, but notes that most of the ingredients are unknown to us today. There is, however, evidence from the Talmud and later Jewish writings that allow us to speculate with a degree of confidence what those unknowns may have been:

And YHWH said unto Moses, "Take unto thee sweet spices, stacte and onycha, and galbanum; these sweet spices with pure frankincense: of each shall there be a like weight. And thou shalt make it a perfume, a confection after the art of the apothecary, salted together, pure and holy." (Exodus 30:34-35, my translation)
The Talmud (Mishna. Kerithoth 6b) adds myrrh, cassia, cinnamon, spikenard, saffron, costus, agarwood, and mastic, all of which contain psychoactive components. Five further substances are described not as ingredients but as adjuncts: Carshina lye, Cyprus wine, Sodom salt, ma'aleh 'ashan and Jordan amber. Taboos were in place regarding its manufacture: "If one omits one of the ingredients, he is liable to the penalty of death" (Mishna. Kerithoth 6b).

\section{USE OF THE INCENSE}

The High Priest was anointed before entering the chamber, so his P450s would already be inhibited and inhaled psychoactives would remain active for longer.

He shall take a censer full of burning coals of fire from off the altar before $Y H W H$, and his hands full of sweet incense beaten small, and bring it within the veil: And he shall put the incense upon the fire before $Y H W H$, that the cloud of the incense may cover the mercy seat that is upon the testimony (Leviticus 16:12).

Two handfuls of finely ground incense in a small wellsealed chamber would have produced an extremely dense cloud, and Strassman (2014, p. 101) points out that the cloud itself was the medium of communication, translating Leviticus 16:2 as "Through the agency of the cloud I will appear upon the Ark-cover." While he finds "little, if any, evidence in the text [that] Hebrew Bible personalities experienced prophecy by ingesting psychoactive plants or drugs" (2014, p. 14), he concedes that this method "suggests an exogenous mind-altering agent" (2014, p. 101), although he stops short of inquiring into the psychopharmacology of the ingredients.

\section{ADJUNCTS}

The role of Cyprus wine and Carshina lye indicate a refined alchemy of production.

Why was Carshina lye brought? To refine the onycha, that it be pleasant.

Why was Cyprus wine brought? To steep the onycha, that it be pungent (Heger, 1997, p. 94).

There may be another connection to Egyptian priestcraft here, as Plutarch describes how kyphi was also steeped in wine (Byl, 2012).

Various candidates for Jordan amber have been suggested (Touger, 1987, 2.2, footnote 5). The identity of ma'aleh 'ashan was jealously guarded even from the scribes who recorded the traditions in the Talmud (Mishna. Yoma 38a), although its purpose is indicated by its name which means "that which causes smoke to rise" (Abramowitz, 2012, p. 109); one possibility is Leptadenia pyrotechnica (Sand, 2012, p. 59). According to the Jewish sage Rashi (Mishna. Menahot 21a), Sodom salt is a finely pulverized salt (the spices are "salted together" in the recipe). Sand (2012, p. 59) notes that the high potassium content of salt from Sodom would add to the smoke-raising capacity of the incense. 


\section{IDENTITIES AND PSYCHOPHARMACOLOGY OF INCENSE INGREDIENTS}

\section{Stacte}

Stacte is nattaf in Hebrew. The word derives from a root meaning "to drop, drip, distil, prophesy, preach, discourse" (Strong's, H5198), suggesting something sublime emerging gradually. Elsewhere it refers to raindrops distilled out from vapor in the air (Job 36:27). Dioscorides and Theophrastus consider it to be distilled myrrh (quoted in Janick, 2012), while for Pliny it is a gum that flows from the myrrh tree without cutting collected before the harvest. Other liquid forms have been proposed (Abrahams, 1979), but it being finely ground suggests the "drops" had hardened.

\section{Onycha}

The first Greek version of the Old Testament translated sh'cheleth as onyx, meaning "claw" or "fingernail." For many Christian theologians, it is part of a mollusk shell, although there are problems with this identification. The strongest objection is that mollusks are not kosher, rather they are described as an abomination (Leviticus 11:10), and unclean animals are excluded from ritual as well as food (Mishna. Shabbat 28a). An abomination in the Holiest of Holy places in the Israelite cosmos seems unlikely.

The Talmud states that onycha comes "from the ground, but not from the tree" (Mishna. Kerithoth 6b), which excludes the mollusk and also the benzoin and bdellium proposed by some scholars (Abrahams, 1979), as both are from trees. The renowned 10th century Rabbi Saadia Gaon considered onycha to be labdanum resin exuded from two species of rockrose shrubs (not trees), Cistus ladanifer and Cistus creticus (Walker, 1979, p. 241). Abrahams (1979) and the Illustrated Dictionary of the Bible concur with this identification. The Hebrew root means "to peel off" (Gesenius, 1857, p. 814), which may be related to the method by which labdanum is traditionally collected, either scraped from the shrubs or from the beards of goats that eat the shrubs (Wise, 2009). The scraping tool is a type of claw, perhaps explaining why sh'cheleth is rendered in Greek as onycha meaning claw.

Labdanum contains crocin, crocetin, and safranal, as well as picrocrocin and zeaxanthin, which the body metabolizes into safranal (Frusciante et al., 2014). Safranal is a GABAreceptor agonist and anti-depressant (Al-Snafi, 2016). It also stimulates $\beta 2$-adrenoreceptors (Srivastava, Ahmed, Dixit, \& Saraf, 2010), improving circulation and aiding distribution, especially in combination with crocetin, which is a vasodilator (Llorens et al., 2015). Crocin also has anti-depressant properties (Al-Snafi, 2016), and it gives rats erections (Hosseinzadeh, Ziaee, \& Sadeghi, 2008).

\section{Galbanum}

The most popular attribution is Ferula gummosa (Duke, 2008, p. 185), a sedative with components acting opioid receptors (Fazly Bazaz, Parsaei, \& Haririzadeh, 1997). It also contains several ACH inhibitors, including auraptene, farnesiferol A, and kellerin (Sayyah \& Mandgary, 2003).
The psychoactive and nootropic properties of $\mathrm{ACH}$ inhibitors have been discussed above.

\section{Frankincense}

Another gift of the Magi, frankincense is one of the most exalted substances in the Christian tradition, burned to the Canaanite Ba'al before it was burned to YHWH, and to Ra in Egypt (Atchley, 1909, p. 11; Guardini, 2015). Its value could justify a 6 month, 1,500-mile camel trek from Oman braving desert bandits, which is a lot of effort for a pleasant aroma - but there is more to frankincense than scent.

The species of Boswellia tree is disputed (Duke, 2008). Most propose Boswellia sacra, others prefer Boswellia carterii (Tucker, 1986), and botanists disagree over whether these are in fact different species. In any case, they are roughly similar in terms of their constituents (Woolley et al., 2012). The dehydroabietic acid component is a GABA-receptor modulator with tranquillizing, antidepressant, and anxiolytic actions in mice (Drahl, 2008; Rueda et al., 2014). The incensole acetate has potent actions on the TRPV3 ion channel (Moussaieff et al., 2008), which is involved in temperature sensation in the skin and also widely distributed in the brain where its functions are unknown. According to Drahl (2008), frankincense possibly "augments the euphoric feeling produced during religious functions." Other components discussed above include $\alpha$ - and $\beta$-pinene, camphene, sabinene, myrcene, limonene, and linalool (Li, Yang, Li, Zhang, \& Tang, 2016; Woolley et al., 2012).

\section{Cinnamon, cassia, and myrrh}

In addition to the psychopharmacology already discussed, eugenol and $\alpha$-pinene are bronchodilators (Falk et al., 1990; Mali \& Dhake, 2011) that would increase absorption. Eugenol is also a mast cell stabilizer suppressing histamine (Mali \& Dhake, 2011), and thereby reducing the irritation dense smoke might provoke. The anti-spasmodic elemicin suppresses the cough reaction (Mali \& Dhake, 2011). Eugenol, cinnamic aldehyde, and $\alpha$-terpeniol in cinnamon are anti-inflammatory agents, which would also mitigate lung issues (Mali \& Dhake, 2011).

\section{Saffron}

Saffron is the stigma of Crocus sativus. It contains safrol, safranal, and crocin (Srivastava et al., 2010), which are all discussed above. Rabbi Immanuel Löw describes an ancient Passover recipe with saffron mixed into wine (along with something that might be cannabis; cited in Bennett, 2016), and according to Georg Most, quoted in Rätsch (2005, p. 211), "saffron comes close to opium; in low doses, it excites, cheers, and produces laughter... in high doses it sedates, promotes sleep, sopor." Pliny described how it "has a gentle effect upon the head, and whets the sex drive" (Rätsch, 2005). This has been demonstrated in rats for crocin, which causes them to have more erections than usual (Hosseinzadeh et al., 2008). Saffron also increases bioavailability and enhances absorption of other drugs (Javadi, Sahebkar, \& Emami, 2013). 


\section{Costus}

Saussurea costus is used in Asia as an aphrodisiac, in Chinese joss sticks and in Ayurvedic prescriptions (Ratsch \& Müller-Ebeling, 2003), and as a traditional Persian remedy for cognitive disorders (Ahmadian-Attari et al., 2015). In addition to crocin, it contains dehydrocostus lactone and costunolide, which are both neuroleptics, analgesics, and sedatives that cause motor incoordination and catalepsy in rats (Okugawa, Ueda, Matsumoto, Kawanishi, \& Kato, 1996). Costunolide may also play a neuroprotective role, as it protects dopaminergic cells against dopamine-induced apoptosis (Ham, Lee, Shin, Kim, \& Mar, 2012).

\section{Agarwood}

Valued in Chinese medicine for qi-regulating, carminative, and analgesic properties, and used as incense in Buddhist, Hindu, and Islamic rites, agarwood is a resin produced by various species of Aquilaria tree when damaged or infected. Its 300 isolated compounds variously potentiate GABA receptors, inhibit $\mathrm{ACH}$ and both serotonin and norepinephrine reuptake, and have sleep-inducing, sedative, and potent antidepressant activities in animals (Wang et al., 2018).

\section{Spikenard}

Spikenard is Nardostachys jatamansi. It is "very costly" in the Bible, such that Judas complains when it is used liberally on Jesus' feet (John 12:3-5). In mice, spikenard exhibits anti-depressant activity (Dhingra \& Goyal, 2008). The major constituent is calarene $(82.3 \%)$, which when taken alone has an "instant and intense" sedative effect. Spikenard itself is a sedative at low doses and a stimulant at high doses (Takemoto, Ito, Shiraki, Yagura, \& Honda, 2007), suggesting more complex psychopharmacology.

Spikenard impacts serotoninergic, dopaminergic, and GABAergic function, and improves learning and memory in mice (Sahu et al., 2016). The mechanism may be facilitating cholinergic transmission, meaning that it might synergize with $\mathrm{ACH}$ inhibitors such as $\alpha$-pinene for a cumulative nootropic effect. Given that Ointment and Incense contain GABA-receptor modulators, opioid-receptor agonists and THC, all of which disrupt memory formation (Roozendaal \& McGaugh, 2011; Schoeler \& Bhattacharyya, 2013), spikenard might have served an important function of helping the High Priest remember the details of his divinatory experience. It also has neuroprotective properties (Prabhu \& Karanth, 1994; Sahu et al., 2016).

\section{THE PILLAR OF SMOKE}

When the thick veil was drawn back at the end of the fumigation rite, smoke would come pouring out of the Holy of Holies and through the Tabernacle to the entrance, where it would rise up into the sky under the influence of ma'aleh "ashan, "that which causes smoke to rise." This is what people outside see:

When Moses entered into the Tabernacle the cloudy pillar revealed, then it appeared/arose at the entrance of the
Tabernacle. It talked with Moses. All the people [outside] saw the cloudy pillar appear/arise at the Tabernacle entrance: and all the people rose up and worshipped, every man in his tent entrance. (Exodus 33: 9-11, my translation) (Even considering the flexibility of Hebrew, most Bibles mistranslate this chapter egregiously. For an explanation of my translation, see Nemu, 2016, pp. 182-183)

This pillar of smoke famously guides (nachah) the Children of Israel (Exodus 13:21). This could be interpreted as it guides the tribe by conversing with its leader in a rite of divination involving an entheogenically induced ASC. This format is common to many shamanistic cultures.

\section{CONCLUSIONS}

Even excluding speculation about cannabis, the Incense and Ointment contained a broad range of enzyme inhibitors and psychoactive components with mood-altering, anxiolytic, sedative, hypnotic, aphrodisiac, nootropic, stimulant, and euphorigenic properties. But would they be entheogenic?

Human experience is complex, especially human experience of the transcendental. The Bible expresses what many psychonauts know, that the same substance can produce different effects in different settings. Myrrh, for example, is mentioned in contexts implying analgesia (Mark 15:23) and aphrodisiac properties (Proverbs 7:16-18), as well as the prophetic states of the Tabernacle. Spiritually inclined people taking psychedelics for spiritual purposes score higher on the Mysticism Scale (Neitzke-Spruill \& Glasser, 2018) than atheists out partying, and all 10 divinity students given psilocybin in church on Good Friday reported mystical experiences that they still described 25 years later as formative (Doblin, 1991; Pahnke, 1969). Israelite priests anointed with the Holy Ointment expected to encounter YHWH and be changed by the experience, to become capable of ministering to Him and understanding His will.

If an experience of YHWH can be induced by a psychoactive concoction, should we conclude that $\mathrm{He}$ is a byproduct of psychopharmacology? Old Testament scripture indicates otherwise, with various ASC, visions and visitations, convulsions, compulsions, and conversations not triggered by plants but by fasting, meditation, stress, holding postures, visiting places of power, or happening spontaneously (Strassman, 2014, p. 260). Such techniques are common in shamanistic traditions.

The basic assumption of neurotheology is that mystical and spiritual experiences are triggered by exogenous or endogenous chemicals, and therefore that their ultimate source is the brain. Strassman turns this around with his concept of theoneurology (2014, pp. 10-13), where entities from transcendent realms communicate via the brain. While I respectfully disagree with aspects of Strassman's approach to theology and psychedelics (Nemu, 2017), and feel that his characterization of "often murderous" shamanistic practice lacks nuance (Strassman, 2014, p. 57), the concept of theoneurolgy is insightful and timely. It could be argued that neurotheology, in denying the cosmologies and experiences of nearly every culture in history except one - the postEnlightenment Euro-American humanistic project dominated 
by logical positivism - is an exercise in neocolonialism. Ultimately, the brain cannot understand the brain, nor can the mind understand the mind, for an eye cannot see itself. In the absence of a mystical experience or synchronicity of mindblowing strangeness, choosing between theoneurology or neurotheology is a matter of faith or personal preference. Theoneurology gives to ancient sages and modern shamans a degree of respect that neurotheology does not.

The Ointment and Incense are arguably not just psychoactive but entheogenic, revealing powers that already exist, as spectacles bring a face into focus or a microscope reveals blood cells. In the Bible, divine interactions with the world are mostly interventions into the thoughts, visions, dreams, and drives of legendary but ordinary human beings undergoing non-ordinary experiences - the stuff of psychiatry, parapsychology, and mysticism.

The Ramban, who was one of the greatest sages of Jewish history, plays a word game that introduces the Bible as a guide to mental experience (Nahmanides, 1960, p. 34). He suggests an alternative pronunciation of the first 14 letters of the Bible, which can be read to mean "In the head Elohim has been/is being created" (Nemu, 2016, p. 17). A close reading of the Old Testament reveals not just YHWH but various names of God with competing agendas, consistent in their own behaviors but sometimes opposing each other (Genesis $22: 2,12$ ) and sometimes opposed by the prophets for the good of the tribe (Exodus 32:12). There are entheogens in the Bible, but this book also has plenty to teach us about other factors driving experience "in the head," about processes of perception and cognition both ordinary and non-ordinary.

Acknowledgements: The author would like to thank Luke Williams and Dominic Le Prevost for help with the molecular biology, Chris Bennett for ethnography, and Nadav Modlin with the Hebrew.

Conflict of interest: The author declares no conflict of interest.

\section{REFERENCES}

69Ron. (2010, August 24). Elemicin taken in enteric coated capsules - A trip report. Retrieved from https://www. dmt-nexus.me/forum/default.aspx?g=posts\&t $=14867$

Abrahams, H. J. (1979). Onycha, ingredient of the ancient Jewish incense: An attempt at identification. Economic Botany, 33(2), 233-236. doi:10.1007/BF02858295

Abramowitz, J. (2012). The taryag companion. Bloomington, IN: Xlibris.

Atchley, J. E. G. C. F. (1909). A history of the use of incense in divine worship. London: Longmans, Green \& Co.

Aegineta, P. (1847). The seven books of Paulus Aegineta (Vol. 3, A. Francis, Trans.). London, UK: The Sydenham Society.

Ahmadian-Attari, M. M., Ahmadiani, A., Kamalinejad, M., Dargahi, L., Shirzad, M., \& Mosaddegh, M. (2015). Treatment of Alzheimer's disease in Iranian traditional medicine. Iranian Red Crescent Medical Journal, 17(1), e18052. doi:10.5812/ ircmj. 18052
Alderman, S., Frederickson, D., Milbrath, G., Montes, N., NarroSanchez, J., \& Odvody, G. (1999). A laboratory guide to the identification of claviceps purpurea and claviceps africana in grass and sorghum seed samples. Salem, OR: Oregon Department of Agriculture.

Al-Hasani, R., \& Bruchas, M. R. (2011). Molecular mechanisms of opioid receptor-dependent signaling and behavior. Anesthesiology, 115(6), 1363-1381. doi:10.1097/aln.0b013e318238bba6

Al-Snafi, A. E. (2016). The pharmacology of Crocus sativus: A review. IOSR Journal of Pharmacy, 6(6), 8-38.

Ascendancy-Mike. (2009, June 2). Commiphora molmol (myrrh) terpene fraction isolates. Retrieved from http://www.entheogennetwork.com/forums/viewtopic.php? $\mathrm{f}=10 \& \mathrm{t}=20563 \&$ start $=50$

Asghar, A. A., Irshad, M. A., \& Majeed, M. (2016). Elucidating the therapeutic potential of nutraceuticals. In A. Grumezescu (Ed.) Nutraceuticals: Nanotechnology in the agri-food industry (Vol. 4, pp. 231-270). Amsterdam, The Netherlands: Academic Press.

Baden, J. S. (2010). The original place of the priestly manna story in Exodus 16. Zeitschrift für die alttestamentliche Wissenschaft, 122(4), 491-504. doi:10.1515/zaw.2010.035

Bang, M., Choi, S. Y., Jang, T., Kim, S. K., Kwon, O., Kang, T., Won, M. H., Park, J., \& Baek, N. I. (2002). Phytol, SSADH inhibitory diterpenoid of Lactuca sativa. Archives of Pharmacal Research, 25(5), 643-646. doi:10.1007/ BF02976937

Benet, S. (1975). Early diffusion and folk uses of hemp. In V. Rubin (Ed.), Cannabis and culture (pp. 39-49). The Hague: Mouton Publishers.F

Bennett, C. (2010). Cannabis and the soma solution. Waterville, OR: TrineDay LLC.

Bennett, C. (2016, July 27). The Biblical Ezra's cup of Hashish infused wine? Retrieved from https://www.cannabisculture. com/content/2016/07/27/the-biblical-ezras-cup-of-hashish/

Bento, A. F., Marcon, R., Dutra, R. C., Claudino, R. F., Cola, M., Leite, D. F., \& Calixto, J. B. (2011). $\beta$-caryophyllene inhibits dextran sulfate sodium-induced colitis in mice through CB2 receptor activation and PPARgamma pathway. The American Journal of Pathology, 178(3), 1153-1166. doi:10.1016/j. ajpath.2010.11.052

Ben-Yehoshua, S., Borowitz, C., \& Hanuš, L. O. (2012). Frankincense, myrrh, and balm of gilead: Ancient spices of southern arabia and judea. Horticultural Reviews, 39, 1-76. doi:10. 1002/9781118100592.ch1

Bertz, R. J., \& Granneman, G. R. (1997, March). Use of in vitro and in vivo data to estimate the likelihood of metabolic pharmacokinetic interactions. Clinical Pharmocokinetics, 32(3), 210-258. doi:10.2165/00003088-199732030-00004

Biologyguy. (2013, November 24). An interesting legal high: an experience with nutmeg (exp83145). Retrieved from www. erowid.org/exp/83145

Blom, J. D. (2009). A dictionary of hallucinations. London, UK: Springer.

Bodenheimer, F. S. (1947). The manna of Sinai. The Biblical Archaeologist, 10(1), 1. doi:10.2307/3209227

Bonar, H. (1857). The desert of Sinai, notes of a spring journey from Cairo to Beersheba. London, UK: James Nisbet \& Co.

Bond, W. S. (1991). Ethnicity and psychotropic drugs. Clinical Pharmacology, 10(6), 467-470. doi:10.1177/02698 81107082105 
Bowery, N. G., \& Smart, T. G. (2006). GABA and glycine as neurotransmitters: A brief history. British Journal of Pharmacology, 147(1), 109-119. doi:10.1038/sj.bjp.0706443

Brum, L., Emanuelli, T., Souza, D. O., \& Elisabetsky, E. (2001). Effects of linalool on glutamate release and uptake in mouse cortical synaptosomes. Neurochemical Research, 26, 191-194. doi:10.1023/A:1010904214482

Buchbauer, G., Jirovetz, L., Jäger, W., Plank, C., \& Dietrich, H. (1993, June). Fragrance compounds and essential oils with sedative effects upon inhalation. Journal Pharmaceutical Science, 82(6), 660-664. doi:10.1002/jps.2600820623

Buckley, A. W., Sassower, K., Rodriguez, A. J., Jennison, K., Wingert, K., Buckley, J., Thurm, A., Sato, S., \& Swedo, S. (2011). An open label trial of donepezil for enhancement of rapid eye movement sleep in young children with autism spectrum disorders. Journal of Child and Adolescent Psychopharmacology, 21(4), 353-357. doi:10.1089/cap.2010.0121

Byl, S. A. (2012). The essence and use of perfume in ancient Egypt (Master's thesis). University of South Africa, Pretoria. Retrieved from https://core.ac.uk/download/pdf/13235969.pdf

Dhingra, D., \& Goyal, P. K. (2008). Inhibition of MAO and GABA: Probable mechanisms for antidepressant-like activity of Nardostachys jatamansi DC. in mice. Indian Journal of Experimental Biology, 46, 212-218. Retrieved from https:// pdfs.semanticscholar.org/0c8e/6c2ec450e93af5811432d8d9d3 1655cb4757.pdf

DMtriptamine285. (2012, July 27). Afoafs myrrh essential oil experiments. Retrieved from https://drugs-forum.com/threads/ afoafs-myrrh-essential-oil-experiments.190508/

Doblin, R. (1991). Pahnke's "Good Friday experiment”: A longterm follow-up and methodological critique. Journal of Transpersonal Psychology, 23, 1-28. Retrieved from http:// www.atpweb.org/jtparchive/trps-23-91-01-001.pdf

Dolara, P., Luceri, C., Ghelardini, C., Monserrat, C., Aiolli, S., Luceri, F., Lodovici, M., Menichetti, S., \& Romanelli, M. N. (1996, January 4). Analgesic effects of myrrh. Nature, 379(6560), 29. doi:10.1038/379029a0

Douglas, N., \& Slinger, P. (2000). Sexual secrets: The alchemy of ecstasy. Rochester, VT: Destiny Books.

Drahl, C. (2008). What's that stuff? Frankincense and myrrh: Culture and chemistry meet in fragrant plant-based incense. Chemical and Engineering News, 86(51), 38. doi:10.1021/ cen-v086n051.p038

Duke, J. A. (2002). CRC handbook of medicinal herbs (2nd ed.). Boca Raton, FL: CRC Press.

Duke, J. A. (2008). Handbook of medicinal plants of the Bible. Boca Raton, FL: CRC Press.

Ebadi, N., Masoomi, F., Yakhchali, M., Sadati-Lamardi, S., Shams-Ardakani, M., Sadeghpour, O., Raiesdana, A., \& Ramezany, F. (2016). Convoy drugs in traditional Persian medicine: The historical concepts of bioavailability and targeting. Traditional and Integrative Medicine, 1, 18-27. Retrieved from http://jtim.tums.ac.ir/index.php/jtim/article/view/3/0

Elufioye, T. O., Berida, T. I., \& Habtemariam, S. (2017). Plants-derived neuroprotective agents: Cutting the cycle of cell death through multiple mechanisms. Evidence-Based Complementary and Alternative Medicine, 2017, 1-27. doi:10.1155/2017/3574012

Escondido, N. (2015). The truth about indicas and sativas. High Times. Retrieved from https://hightimes.com/grow/the-truthabout-indicas-and-sativas/
Eschotado, A. (1998). Historia general de las drogas [A general history of drugs] (7th ed.). Madrid, Spain: Alianza Editorial.

Faria, A., \& Calhau, C. (2011). The bioactivity of pomegranate: Impact on health and disease. Critical Reviews in Food Science and Nutrition, 51(7), 626-634. doi:10.1080/1040839 1003748100

Falk, A. A., Hagberg, M. T., Löf, A. E., Wigaeus-Hjelm, E. M., \& Wang, Z. P. (1990). Uptake, distribution and elimination of alpha-pinene in man after exposure by inhalation. Scandinavian Journal of Work Environ Health, 16(5), 372-378. doi:10.5271/sjweh.1771

Fausto, C. (2012). Warfare and shamanism in Amazonia. New York, NY: Cambridge University Press.

Fazly Bazaz, B. S., Parsaei, H., \& Haririzadeh, G. (1997). Evaluation of antinociceptive and antimicrobial activities of galbanum plant (Ferula gummosa). Daru Journal of Faculty and Pharmacy, 7, 1-22.

Feliks, Y. (2001, March 10). Hyoscyamus aureus and its relationship to the headdress of the High Priest. Bar-Ilan University's Parashat Hashavua Study Center. Retrieved from https://www. biu.ac.il/JH/Parasha/eng/tetzaveh/fel.html

Flattery, D. S., \& Schwartz, M. (1989). Haoma and harmaline: The botanical identity of the Indo-Iranian sacred hallucinogen 'soma' and its legacy in religion, language, and MiddleEastern folklore. Berkeley, CA: University of California Press.

Flickedbic. (2011). Re: The psychedelic effects of sweet basil oil (methyl chavicol). Retrieved from https://www.tapatalk. com/groups/herbsmxf/the-psychedelic-effects-of-sweet-basiloil-methyl-t3784181-s100.html

Flickedbic. (2014). Re: Get high without the drugs [Re: Universe] \#19635435. Retrieved from https://www.shroomery.org/ forums/showflat.php/Number/19632792

Friedman, R. S., \& Förster, J. (2001). The effects of promotion and prevention cues on creativity. Journal of Personality and Social Psychology, 81(6), 1001-1013. doi:10.1037/00223514.81.6.1001

Frusciante, S., Diretto, G., Bruno, M., Ferrante, P., Pietrella, M., Prado-Cabrero, A., Rubio-Moraga, A., Beyer, P., GomezGomez, L., Al-Babili, S., \& Giuliano, G. (2014). Novel carotenoid cleavage dioxygenase catalyzes the first dedicated step in saffron crocin biosynthesis. Proceedings of the National Academy of Sciences of the United States of America, 111(33), 12246-12251. doi:10.1073/pnas.1404629111

Gesenius, W. (1857). Hebrew and Chaldee lexicon to the Old Testament scriptures (S. P. Tregelles, Trans.). London, UK: Bagster.

Gilad, E. (2013, June 30). Word of the day/Samim. Haaretz News. Retrieved from https://www.haaretz.com/.premium-word-ofthe-day-samim- 1.5288250

Gordon, A. H., \& Schwabe, C. W. (2004). The quick and the dead: Biomedical theory in ancient Egypt. Leiden, The Netherlands: Brill.

Graham, K. (2015, May 26). Scythian gold vessels used in 'hemp rituals.' Archaeology News Network. Retrieved from http:// archaeologynewsnetwork.blogspot.co.uk/2015/05/scythian-goldvessels-used-in-hemp.html\#.VWcNeusxmU0

Guardini, R. (2015). Sacred signs. St. Louis, MO: Createspace.

Halcpath. (2007, June 26). Playing with them: An experience with cloves (exp43660). Retrieved from https://www.erowid.org/ experiences/exp.php?ID $=43660$ 
Ham, A., Lee, S., Shin, J., Kim, K., \& Mar, W. (2012). Regulatory effects of costunolide on dopamine metabolism-associated genes inhibit dopamine-induced apoptosis in human dopaminergic SH-SY5Y cells. Neuroscience Letters, 507(2), 101-105. doi:10.1016/j.neulet.2011.10.037

Hanuš, L. O., Rosenthal, D., ezanka, T., Dembitsky, V. M., \& Moussaief, A. (2008). Fast and easy GC/MS identification of myrrh resins. Pharmaceutical Chemistry Journal, 42(12), 719-720. doi:10.1007/s11094-009-0209-z

Harada, M., \& Yano, S. (1975). Pharmacological studies on Chinese cinnamon. II. Effects of cinnamaldehyde on the cardiovascular and digestive systems. Chemical and Pharmaceutical Bulletin, 23(5), 941-947. doi:10.1248/cpb.23.941

Heger, P. (1997). The development of incense cult in Israel. New York, NY: Walter de Gruyter.

Herodotus. (1996). Histories (G. Rawlinson, Trans.). Ware, UK: Wordsworth Editions.

Hidaka, M. (2005). Effects of pomegranate juice on human cytochrome p450 3A (CYP3A) and carbamazepine pharmacokinetics in rats. Drug Metabolism and Dispositoin, 33(5), 644-648. doi:10.1124/dmd.104.002824

Hiroshi, I., Yasuhiro, T., Tepy, U., Shigetoshi, K., Akira, H., \& Tadashi, W. (2004). Inhibition of human liver microsomal CYP3A4 and CYP2D6 by extracts from 78 herbal medicines. Journal of Traditional Medicines, 21(1), 42-50. doi:10.11339/ jtm. 21.42

Hosseinzadeh, H., Ziaee, T., \& Sadeghi, A. (2008). The effect of saffron, Crocus sativus stigma, extract and its constituents, safranal and crocin on sexual behaviors in normal male rats. Phytomedicine, 15(6-7), 491-495. doi:10.1016/j.phymed. 2007.09.020

Jacky. (2009, April 28). Re: Commiphora molmol (myrrh) terpene fraction isolates. Retrieved from http://www.entheogennetwork.com/forums/viewtopic.php?f=10\&t=20563\&start=10

Janick, J. (Ed.). (2012). Horticultural reviews (Vol. 102). Hoboken, NJ: John Wiley \& Sons.

Javadi, B., Sahebkar, A., \& Emami, S. A. (2013). A survey on saffron in major Islamic traditional medicine books. Iranian Journal of Basic Medicine Sciences, 16(1), 1-11. Retrieved from https://www.ncbi.nlm.nih.gov/pmc/articles/PMC3637900/

Jayatilake, A., Poole, S. K., Poole, C. F., \& Chichila, T. M. P. (1995). Simultaneous microsteam distillation-solventextraction for the isolation of semivolatile flavour compounds from Cinnamomum and their separation by series coupledcolumn gas chromatography. Analytica Chimica, 30, 147-162. doi:10.1016/0003-2670(94)00445-r

Joshi, R. K. (2014). Chemical composition and antimicrobial activity of the essential oil of Ocimum basilicum L. (sweet basil) from Western Ghats of North West Karnataka, India. Ancient Science of Life, 33(3), 149-156. doi:10.4103/0257-7941.144618

Kannappan, R., Gupta, S. C., Kim, J. H., Reuter, S., \& Aggarwal, B. B. (2011). Neuroprotection by spice-derived nutraceuticals: You are what you eat! Molecular Neurobiology, 44(2), 142-159. doi:10.1007/s12035-011-8168-2

Kendall, D., \& Alexander, S. (Eds.). (2017). Advances in pharmacology: Cannabinoid pharmacology. London, UK: Academic Press.

Kimura, Y., Ito, H., \& Hatano, T. (2010). Effects of mace and nutmeg on human cytochrome P450 3A4 and 2C9 activity. Biological Pharmacology Bulletin, 33(12), 1977-1982. doi:10.1248/bpb.33.1977
Kohlert, C., Rensen, I. V., März, R., Schindler, G., Graefe, E. U., \& Veit, M. (2000). Bioavailability and pharmacokinetics of natural volatile terpenes in animals and humans. Planta Medica, 66(6), 495-505. doi:10.1055/s-2000-8616

Li, X., Yang, Y., Li, Y., Zhang, W. K., \& Tang, H. (2016). $\alpha$-Pinene, linalool, and 1-octanol contribute to the topical antiinflammatory and analgesic activities of frankincense by inhibiting COX-2. Journal of Ethnopharmacology, 179, 22-26. doi:10.1016/j.jep.2015.12.039

Liao, J.-C., Deng, J.-S., Chiu, C.-S., Hou, W.-C., Huang, S.-S., Shie, P.-H., \& Huang, G.-J. (2012). Anti-inflammatory activities of Cinnamomum cassia constituents in vitro and in vivo. Evidence-Based Complementary and Alternative Medicine, 2012(5), 429320. doi:10.1155/2012/429320

Llorens, S., Mancini, A., Serrano-Díaz, J., D’Alessandro, A. M., Nava, E., Alonso, G. L., \& Carmona, M. (2015). Effects of crocetin esters and crocetin from Crocus sativus L. on aortic contractility in rat genetic hypertension. Molecules, 20(9), 17570-17584. doi:10.3390/molecules200917570

Lozano, I. (1993). Estudios y documentos sobre la historia del cáñamo y del hachis en el Islam medieval [Studies and documents on the history of cannabis and hashish in medieval Islam] (Doctoral dissertation). Universidad de Granada, Granada, Spain.

MacDonald, N. M. (2008). What did the ancient israelites eat? Grand Rapids, MI: William B. Eerdmans.

Mali, R. G., \& Dhake, A. S. (2011). A review on herbal antiasthmatics. Oriental Pharmacy and Experimental Medicine, 11(2), 77-90. doi:10.1007/s13596-011-0019-1

McGovern, P. E. (2003). Ancient wine: The search for the origins of viniculture. Princeton, NJ: Princeton University Press.

Meesters, R. J., Duisken, M., \& Hollender, J. (2007). Study on the cytochrome P450-mediated oxidative metabolism of the terpene alcohol linalool: Indication of biological epoxidation. Xenobiotica, 37(6), 604-617. doi:10.3109/00498250701393191

Merkur, D. (2000). The mystery of manna: The psychedelic sacrament of the Bible. Rochester, VT: Park Street Press.

Michael, S. (2015). Adam's nose, and the making of humankind. London, UK: Imperial College Press.

Miczak, M. A. (2001). Henna's secret history: The history, mystery \& folklore of henna. San Jose, CA: Writers Club Press.

Moonshoe. (2015, December 30). Myrrh is a psychoactive opiod agonist. Retrieved from https:/www.shroomery.org/forums/ showflat.php/Number/22635993/fpart/3/vc/1\#22635993

Moss, M., Hewitt, S., Moss, L., \& Wesnes, K. (2008). Modulation of cognitive performance and mood by aromas of peppermint and ylang-ylang. International Journal of Neuroscience, 118(1), 59-77. doi:10.1080/00207450601042094

Moussaieff, A., Rimmerman, N., Bregman, T., Straiker, A., Felder, C. C., Shoham, S., Kashman, Y., Huang, S. M., Lee, H., Shohami, E., Mackie, K., Caterina, M. J., Walker, J. M., Fride, E., \& Mechoulam, R. (2008). Incensole acetate, an incense component, elicits psychoactivity by activating TRPV3 channels in the brain. The FASEB Journal, 22(8), 3024-3034. doi:10.1096/fj.07-101865

Mr. Sunday. (2013, January 3). Om Vision Synergy: Nutmeg \& Myrrh. Retrieved from https://www.erowid.org/experiences/ exp.php?ID=95112

Muchtaridi, M., Subarnas, A., Apriyantono, A., \& Mustarichie, R. (2010). Identification of compounds in the essential oil of nutmeg seeds (Myristica fragrans Houtt.) that inhibit locomotor 
activity in mice. International Journal of Molecular Sciences, 11(11), 4771-4781. doi:10.3390/ijms11114771

Nahmanides. (1960). The Commentary of Nahmanides on Genesis (J. Newman, Trans.). Leiden, The Netherlands: E.J. Brill.

Neitzke-Spruill, L., \& Glasser, C. (2018). A gratuitous grace: The influence of religious set and intent on the psychedelic experience. Journal of Psychoactive Drugs, 1(8). doi:10.1080/ 02791072.2018.1494869

Nemu, D. (2016). Neuro-apocalypse. Cornwall, UK: Psychedelic Press.

Nemu, D. (2017). DMT and the Soul of Prophecy, by Rick Strassman. Retrieved from http://psypressuk.com/2017/03/ 22/dmt-soul-prophecy-rick-strassman/

Nowak, J., Woźniakiewicz, M., Gładysz, M., Sowa, A., \& Kościelniak, P. (2016). Development of advance extraction methods for the extraction of myristicin from Myristica fragrans. Food Analytical Methods, 9(5), 1246-1253. doi:10.1007/s12161-015-0300-x

Nunn, J. F. (1996). Ancient Egyptian medicine. Norman, UK: University of Oklahoma Press.

Okugawa, H., Ueda, R., Matsumoto, K., Kawanishi, K., \& Kato, A. (1996). Effect of dehydrocostus lactone and costunolide from Saussurea root on the central nervous system in mice. Phytomedicine, 3(2), 147-153. doi:10.1016/S0944-7113(96) 80028-6

Olsen, R. W. (1991). GABA and inhibitory synaptic transmission in the brain. Seminars in Neuroscience, 3(3), 175-181. doi:10.1016/1044-5765(91)90014-F

Ooi, L. S., Li, Y., Kam, S., Wang, H., Wong, E. Y., \& Ooi, V. E. (2006). Antimicrobial activities of cinnamon oil and cinnamaldehyde from the Chinese medicinal herb Cinnamomum cassia Blume. The American Journal of Chinese Medicine, 34(3), 511-522. doi:10.1142/S0192415X06004041

Pahnke, W. N. (1969). Psychedelic drugs and mystical experience. International Psychiatry Clinics, 5(4), 14-162.

Park, H. M., Lee, J. H., Yaoyao, J., Jun, H. J., \& Lee, S. J. (2010). Limonene, a natural cyclic terpene, is an agonistic ligand for adenosine $\mathrm{A}(2 \mathrm{~A})$ receptors. Biochemical and Biophysical Research Communications, 404(1), 345-348. doi:10.1016/j. bbrc.2010.11.121

Parthasarathy, V. A., Chempakam, B., \& Zachariah, T. J. (Eds.). (2008). Chemistry of spices. Calicut, Kerala: Indian Institute of Spices Research.

Parsche, F., \& Nerlich, A. (1995). Presence of drugs in different tissues of an Egyptian mummy. Fresenius' Journal of Analytical Chemistry, 352(3-4), 380-384. doi:10.1007/BF00 322236

Perez, J. L. (2001). The perpetual flame: Offering acceptable worship unto God. San Jose, CA: Writers Club Press.

Perry, N. S., Houghton, P. J., Theobald, A., Jenner, P., \& Perry, E. K. (2000). In-vitro inhibition of human erythrocyte acetylcholinesterase by Salvia lavandulaefolia essential oil and constituent terpenes. Journal of Pharmacuetical Pharmacology, 52(7), 895-902. doi:10.1211/002235700 1774598

Pertwee, R. G. (Ed.). (2016). Handbook of cannabis. Oxford, UK: Oxford University Press.

Pliny. (1986). Natural history (H. Rackam, Trans.). Cambridge, MA: Harvard University Press.

Prabhu, V., \& Karanth, K. S. (1994). Effects of Nardostachys jatamansi on biogenic amines and inhibitory amino acids in the rat brain. Planta Medica, 60(2), 114-117. doi:10.1055/s-2006959429

Ranasinghe, P., Pigera, S., Premakumara, S., Galappaththy, P., Constantine, G. R., \& Katulanda, P. (2013). Medicinal properties of 'true' cinnamon (Cinnamomum zeylanicum): A systematic review. BMC Complementary and Alternative Medicine, 13(1), 275. doi:10.1186/1472-6882-13-275

Rao, P. V., \& Gan, S. H. (2014). Cinnamon: A multifaceted medicinal plant. Evidence-Based Complementary and Alternative Medicine, 2014, 1-12. doi:10.1155/2014/642942

Rao, V. S., Menezes, A. M., \& Viana, G. S. (1990). Effect of myrcene on nociception in mice. Journal of Pharmacy and Pharmacology, 42(12), 877-878. doi:10.1111/j.2042-7158. 1990.tb07046.x

Rätsch, C. (2005). The encyclopedia of psychoactive plants: Ethnopharmacology and its applications. Rochester, VT: Park Street Press.

Ratsch, C., \& Müller-Ebeling, C. (2003). Encyclopedia of aphrodisiacs. Rochester, VT: Park Street Press.

Rinella, M. A. (2010). Pharmakon: Plato, drug culture, and identity in ancient Athens. New York, NY: Lexington Books.

Ron, Z. (2010). What is it? Interpreting Exodus 16:15. Jewish Bible Quarterly, 38(4). Retrieved from http://www.jbq.jewishbible. org/assets/Uploads/384/384_manna.pdf

Rooks, B. (2014). Ayahuasca and the godhead: An interview with Wahid Azal of the Fatimiya Sufi order. Reality Sandwich. Retrieved from http://realitysandwich.com/219826/ayahuascaand-the-godheadan-interview-with-wahid-azal-ofthe-thefatimiya-sufi-order/

Roozendaal, B., \& McGaugh, J. L. (2011). Memory modulation. Behavioral Neuroscience, 125(6), 797-824. doi:10.1037/ a0026187

Rueda, D. C., Raith, M., Mieri, M. D., Schöffmann, A., Hering, S., \& Hamburger, M. (2014). Identification of dehydroabietc acid from Boswellia thurifera resin as a positive GABAA receptor modulator. Fitoterapia, 99, 28-34. doi:10.1016/j.fitote.2014.09.002

Russo, E. B. (2011). Taming THC: Potential cannabis synergy and phytocannabinoid-terpenoid entourage effects. British Journal of Pharmacology, 163(7), 1344-1364. doi:10.1111/j.14765381.2011.01238.x

Sachse-Seeboth, C., Pfeil, J., Sehrt, D., Meineke, I., Tzvetkov, M., Bruns, E., Poser, W., Vormfelde, S. V., \& Brockmöller, J. (2008). Interindividual variation in the pharmacokinetics of $\Delta$ 9-tetrahydrocannabinol as related to genetic polymorphisms in CYP2C9. Clinical Pharmacology \& Therapeutics, 85(3), 273-276. doi:10.1038/clpt.2008.213

Sadati, S., Ardekani, M. S., Ebadi, N., Yakhchali, M., Dana, A., Masoomi, F., Khanavi, M., \& Ramezany, F. (2016). Review of scientific evidence of medicinal convoy plants in traditional Persian medicine. Pharmacognosy Reviews, 10(19), 33-38. doi:10.4103/0973-7847.176546

Sahu, R., Dhongade, H. J., Pandey, A., Sahu, P., Sahu, V., Patel, D., \& Kashyap, P. (2016). Medicinal properties of Nardostachys jatamansi (a review). Oriental Journal of Chemistry, 32(2), 859-866. doi:10.13005/ojc/320211

Sand, A. (2012). Mystical aromatherapy: The divine gift of fragrance. Twin Lakes, WI: Lotus Press.

Satou, T., Kasuya, H., Maeda, K., \& Koike, K. (2013). Daily inhalation of $\alpha$-pinene in mice: Effects on behavior and organ accumulation. Phytotherapy Research, 28(9), 1284-1287. doi:10.1002/ptr.5105 
Sauneron, S. (2000). The priests of ancient Egypt. Ithaca, NY: Cornell University Press.

Sayyah, M., \& Mandgary, A. (2003). Anticonvulsant effect of Ferula gummosa root extract against experimental seizures. Iranian Biomedical Journal, 7(3), 139-143. Retrieved from https://ibj.pasteur.ac.ir/browse.php?a_id=536\&sid=1\&slc_lang= en\&ppup $=$

Schoeler, T., \& Bhattacharyya, S. (2013). The effect of cannabis use on memory function: An update. Substance Abuse and Rehabilitation, 2013(4), 11-27. doi:10.2147/sar.s25869

Shanon, B. (2008). Biblical entheogens: A speculative hypothesis. Time and Mind, 1(1), 51-74. doi:10.2752/1751696087 83489116

Souto-Maior, F. N., de Carvalho, F. L., de Morais, L. C., Netto, S. M., de Sousa, D. P., \& de Almeida, R. N. (2011). Anxiolyticlike effects of inhaled linalool oxide in experimental mouse anxiety models. Pharmacology Biochemistry and Behavior, 100(2), 259-263. doi:10.1016/j.pbb.2011.08.029

Srivastava, R., Ahmed, H., Dixit, R. D., \& Saraf, S. (2010). Crocus sativus L.: A comprehensive review. Pharmacognosy Reviews, 4(8), 200. doi:10.4103/0973-7847.70919

Stout, S. M., \& Cimino, N. M. (2013). Exogenous cannabinoids as substrates, inhibitors, and inducers of human drug metabolizing enzymes: A systematic review. Drug Metabolism Reviews, 46(1), 86-95. doi:10.3109/03602532.2013.849268

Strassman, R. (2014). DMT and the soul of prophecy: A new science of spiritual revelation in the Hebrew Bible. Rochester, VT: Park Street Press.

Sugawara, Y., Hara, C., Tamura, K., Fujii, T., Nakamura, K., Masujima, T., \& Aoki, T. (1998). Sedative effect on humans of inhalation of essential oil of linalool. Analytica Chimica Acta, 365(1-3), 293-299. doi:10.1016/S0003-2670(97)00639-9

Takemoto, H., Ito, M., Shiraki, T., Yagura, T., \& Honda, G. (2007). Sedative effects of vapor inhalation of agarwood oil and spikenard extract and identification of their active components. Journal of Natural Medicines, 62(1), 41-46. doi:10. 1007/s11418-007-0177-0

Thulin, M., \& Claeson, P. (1991). The botanical origin of Scented Myrrh (Blssabol or Habak Hadi). Economic Botany, 45(4), 487-494. doi:10.1007/BF02930711

Touger, E. (Trans.). (1987). Klei hamikdash in mishne Torah. New York, NY: Moznaim.

Tucker, A. O. (1986). Frankincense and myrrh. Economic Botany, 40(4), 425-433. doi:10.1007/BF02859654
Vale, T. G., Furtado, E. C., Santos, J., \& Viana, G. (2002). Central effects of citral, myrcene and limonene, constituents of essential oil chemotypes from Lippia alba (Mill.) N.E. Brown. Phytomedicine, 9(8), 709-714. doi:10.1078/ 094471102321621304

Varman, R. M., \& Singh, S. (2012). Investigation of effects of terpene skin penetration enhancers on stability and biological activity of lysozyme. AAPS PharmSciTech, 13(4), 1084-1090. doi:10.1208/s12249-012-9840-1

Vitebsky, P. (2001). Shamanism. Norman, UK: University of Oklahoma Press.

Walker, W. (1979). All the plants of the Bible. New York City, NY: Doubleday \& Company.

Wang, S., Yu, Z., Wang, C., Wu, C., Guo, P., \& Wei, J. (2018). Chemical constituents and pharmacological activity of agarwood and aquilaria plants. Molecules, 23(2), 342. doi:10.3390/ molecules 23020342

Wasson, R. G., Hofmann, A., \& Ruck, C. A. P. (1976). The road to Eleusis: Unveiling the secret of the mysteries. Berkeley, CA: North Atlantic Books.

Wenk, G. L. (2010). Your brain on food. New York City, NY: Oxford University Press.

Winkelman, M. J. (2013). Shamanism in cross-cultural perspective. International Journal of Transpersonal Studies, 31(2), 47-62. doi:10.24972/ijts.2012.31.2.47

Wise, E. (2009). An odor of sanctity: The iconography, magic, and ritual of Egyptian incense. Studia Antiqua, 7(1). Retrieved from https://scholarsarchive.byu.edu/studiaantiqua/ vol $7 /$ iss $1 / 8$

Woolley, C. L., Suhail, M. M., Smith, B. L., Boren, K. E., Taylor, L. C., Schreuder, M. F., Chai, J. K., Casabianca, H., Haq, S., Lin, H. K., Al-Shahri, A. A., Al-Hatmi, S., \& Young, D. G. (2012). Chemical differentiation of Boswellia sacra and Boswellia carterii essential oils by gas chromatography and chiral gas chromatography-mass spectrometry. Journal of Chromatography A, 1261, 158-1633. doi:10.1016/j.chroma. 2012.06.073.

Zadoks, J. C. (2008). On the political economy of plant disease epidemics: Capita selecta in historical epidemiology (p. 168). Wageningen, The Netherlands: Wageningen Academic Publication.

Zias, J., Stark, H., Sellgman, J., Levy, R., Werker, E., Breuer, A., \& Mechoulam, R. (1993). Early medical use of cannabis. Nature, 363(6426), 215. doi:10.1038/363215a0 